\title{
Smart method of agricultural drought regionalization: A winter wheat case study
}

\author{
Tomáš STŘEDA ${ }^{1,2}$, Hana STŘEDOVÁ ${ }^{1,2}$, Filip CHUCHMA $^{1,2}$, \\ Josef KUČERA ${ }^{3}$, Jaroslav ROŽNOVSKÝ2 \\ ${ }^{1}$ Faculty of AgriSciences, Mendel University in Brno, \\ Zemědělská 1665/1, 61300 Brno, Czech Republic, e-mail: streda@mendelu.cz \\ 2 Department of Meteorology and Climatology, Czech Hydrometeorological Institute, \\ Brno Branch, Kroftova 43, 61667 Brno, Czech Republic \\ ${ }^{3}$ Department of Land Consolidation, Research Institute for Soil and Water Conservation, \\ Brno Branch, Lidická 25/27, 60200 Brno, Czech Republic
}

\begin{abstract}
The occurrence of drought during flowering (usually from the end of May to the beginning of June) is the most hazardous timing in terms of the possible negative impact of agricultural drought on winter wheat, which is the most cultivated crop in the Czech Republic (about 800000 ha). Lack of water, often accompanied by high temperatures, negatively affects the number of grains in the wheat ear and the tissue development of the developing grain, with consequent impacts on yield and quality of product. With the use of a) long-term time series of agrometeorological data (1961-2010), b) long-term phenological time series of winter wheat (1981-2010), and c) soil conditions data (available water capacity of soils of the Czech Republic) for the arable soil, the ratio of actual evapotranspiration and potential evapotranspiration for the period of 1961-2010, used as an indicator of agricultural drought (lack of water) for wheat, was calculated. The innovative aspect of this categorization of the territory of the Czech Republic according to the risk of occurrence of agricultural drought for winter wheat is considering drought from the aspect of the plant, i.e., evaluation based on the actual consumption of water by the vegetation. This is a very sophisticated procedure. Frequently, water content in soils data, presented as an output of some models, do not fully indicate the possible negative impacts on yield generation because the plants themselves are typically not considered. The method used in this study is universally applicable and allows comparisons of regions at the local, regional, and supra-regional levels. For estimation of the development of agronomic drought in the future, the basic water balances in the growing seasons of 19612010 and 2071-2100 were compared using a climate scenario. The forecast indicates a significant deterioration of agricultural drought in the region with probable direct impacts on agricultural production.
\end{abstract}

Key words: evapotranspiration, soil moisture, phenology, wheat, ALADIN, agroclimatology 


\section{Introduction}

Precipitation in the Czech Republic is characterized by considerable spatial and temporal variability. In addition to certain types of synoptic situations, this variability is also due to orographic influences, such as increase of precipitation with increasing altitude and slope exposure. Additionally, the quantity and distribution of precipitation in central Europe are expected to change in the future (Škvarenina et al., 2009; Nikolova et al., 2016). Climate models predict moderate growth of rainfall by the year 2050, on average, for the whole of the Czech Republic. Compared with the long-term average of 1961-2000, precipitation should increase in Moravia compared to Bohemia, as suggested by the ALADIN model. Furthermore, this model assumes a $15 \%$ reduction in precipitation in winter, an increase in rainfall of up to $20 \%$ in the autumn period, and a $10 \%$ increase in the summer period. A slight decrease in rainfall totals is expected by 2100 according to the outlook. From the point of view of distribution of rainfall over the course of the year, Středová et al. (2011) and Středová and Středa (2015) suggested that there might be an increase in the number of days without precipitation from the current 79.9 days to 141.6 days between 2071 and 2100. A simultaneous increase in the mean sum of effective temperatures above $10^{\circ} \mathrm{C}$ from the current $2717^{\circ} \mathrm{C}$ to $3732^{\circ} \mathrm{C}$ is also predicted. These changes will increase the evapotranspiration requirements of the environment where stands will be exposed. Despite the fact that drought is a relatively recent problem in central Europe (Klimešová et al., 2017; Procházková et al., 2016), it is seen as a long-term serious abiotic stress affecting yields of agricultural crops throughout the world (Boyer, 1982).

The easiest way to define dry areas in the Czech Republic seems to be through the course of the $500 \mathrm{~mm}$ isohyet of average annual precipitation. Calculations of scenario values of potential evapotranspiration predict a significant increase in drought risk in the Czech Republic. As a result of estimation of meteorological and hydrological indexes, central and southern Moravia, central and northwestern Bohemia, and lower and central Polabí and Povltaví will be more vulnerable to drought (Kalvová et al., 2002). Kohut et al. (2009) carried out a detailed analysis of the development of water conditions in the Czech Republic for the period of 1961-2000. The results of the analysis showed that soil moisture is already decreasing at present. 
The limiting value for C3 cereals (e.g., wheat, barley, oat, rye), where there is no reduction in transpiration, is a soil moisture in the root zone value of about $50-65 \%$ of the available water capacity. However, long-term values lower than $45 \%$ of usable water capacity are characteristic of the intensely utilized agricultural areas of the Czech Republic up to about $300 \mathrm{~m}$ above sea level.

Blum (2005) defines the onset of drought as a period when the plant water demand is not satisfied and plant water deficit occurs. Lipiec et al. (2013) define drought as the result of water flow imbalance between the evapotranspiration demands of the environment and the transport of water in the soil-root system. Generally, plant stress caused by drought can be determined by measuring the water potential of leaves (Jones, 200\%). Values of $-0.5 \mathrm{MPa}$ indicate slight stress caused by drought resulting in significant slowing of growth. To the contrary, values of around $-1.5 \mathrm{MPa}$ indicate very strong stress caused by drought, with loss of cell turgescence and wilt.

Drought causes reduction of the number of founding grains during generative phases (Lawlor et al., 1981), and the flowering stage of development is the critical period during which water shortages have the greatest impact. The properties of a plant's root system may increase the plant's ability to receive water. Hence, the root system has received great interest as the organ responsible for the tolerance to drought of some crop varieties (Středa et al., 2012).

The water consumption of cereals varies within about $300-800 \mathrm{l} \mathrm{kg}^{-1}$ of dry matter above ground according to the conditions of the environment and the period of growth. Winter cereals need at least $500-600 \mathrm{~mm}$ of precipitation, or $500-600 \mathrm{~lm}^{-2}$, for high yields and about $8 \mathrm{tha}^{-1}$ or more for the entire growing season. The availability of soil moisture, global radiation, and saturation deficit are the main determinants of transpiration ( $D u$ et al., 2011; She et al., 2012; Zeppel et al., 2008). The daily, as well as the longterm, course of these variables influences the transpiration flow of the plant (Naithani et al., 2012). In the event of drought stress, it is assumed that soil moisture will have the greatest effect on the transpiration process (Matejka et al., 2005). Changes in transpiration intensity are considered an indicator of drought stress on the plant. This inspired the authors to develop an internationally applicable universal method for categorization of areas according to the risk of occurrence of agricultural drought for winter wheat. 


\section{Material and methods}

\subsection{Categorization of the territory of the Czech Republic accord- ing to the risk of occurrence of agricultural drought for winter wheat}

The input data for calculation of the ratio of actual evapotranspiration (aE: evapotranspiration affected by the amount of water in the soil) and potential evapotranspiration ( $\mathrm{pE}$ : the maximum demands on the environment for evaporation and transpiration) consisted of a set of calculated daily values of $\mathrm{aE}$ and $\mathrm{pE}$ for the period of 1961-2010 with the use of a method of calculation according to Penman-Monteith's methodology (Penman, 1948). For the purposes of the entire calculation "Agrometeorological Computing and Information System" AVISO (Kohut, 2007; Kohut et al., 2009) which uses selected algorithms (modified Penman-Monteith method) and is a Czech alternative to the similar English model MORECS (The Meteorological Office Rainfall and Evaporation Calculation System) was used (Thompson et al., 1981; Hough et al., 1997). The model is based on the combined PenmanMonteith's equation for the calculation of evapotranspiration in a modified manner. The input meteorological data are: air temperature and air humidity in the form of water vapor, sunshine duration, wind speed and precipitation. To analyze the actual evapotranspiration (aE) were performed for winter wheat with the using of AVISO model and methodology Allen et al. (1998).

The data were calculated from an input of calculated series of meteorological variables (Skalák et al., 2008) of the points of a regular $10 \times 10 \mathrm{~km}$ grid network (789 points within the Czech Republic). The aE and $\mathrm{pE}$ values for winter wheat were calculated on the basis of the phenological and biological specifics of the species, and the specific hydrolimit was derived for each calculation grid point from the available water capacity layer. The average date of the beginning of flowering was determined from the phenological layer of the beginning of the flowering of winter wheat (1981-2010 i.e. the longest available homogeneous area-wide data series; database of the Czech Hydrometeorological Institute) for each grid point, and the calculation period was set to within 10 days before and 10 days after that date. Long-term (1961-2010) aE and $\mathrm{pE}$ were calculated for each grid point of the specified period. These values were subsequently used to determine the ratio sum $\mathrm{aE} / \mathrm{sum} \mathrm{pE}$, and the resulting set of grid points with the assigned 
$\mathrm{aE} / \mathrm{pE}$ ratios for the period of 1961-2010 was created. A GIS dot layer was subsequently created from these data.

The values for the individual points were interpolated using the local linear regression method with an altitude dependence with the estimated value correction to maintain a value corresponding to the location of the station (ClidataDEM method used in the CLIDATA database of the Czech Hydrometeorological Institute). The resulting raster model was then processed in the ArcGIS 10.3 software environment and subsequently blotted out by the nearest neighbor method. Raster layers were then reclassified into individual categories with a step of 0.04 and converted to polygons. Only areas classified as arable land were selected from the resulting polygon layer. The resulting map output was created in the GIS environment.

\subsection{Potential water balance in the growing season}

The basic parts of the water balance of a given area are precipitation and evapotranspiration, which along with drainage forms the loss component. Because of the complex interactions between soil, vegetation, and atmosphere, evapotranspiration is very difficult to quantify. The total amount of evaporated water depends primarily on the meteorological conditions prevailing at the site. The determining factors are, above all, intensity of sunshine, albedo and surface roughness, wind speed, air temperature, and air humidity. Because this is a large number of factors, reference is made to actual (or potential) evapotranspiration for each crop calculated by the Penman-Monteith equation in the AVISO model (Kohut et al., 2009).

In order to capture the future climate trend, scenario data were created at the Czech Hydrometeorological Institute. The scenario data were created by integration of the regional climate model ALADIN-Climate/CZ within the CECILIA international project. As part of this project, climatic conditions for Central Europe were simulated using ALADIN-Climate/CZ with a resolution of $10 \mathrm{~km}$. The simulation was carried out with using the A1B emission scenario (according to IPPC). Based on simulations of the ALADIN-10 model, the water balance (difference of precipitation and actual evapotranspiration) in the growing season (i.e. April to September) for the periods of 1961-2010 and 2071-2100 was calculated for the Czech Republic (details in Chuchma et al., 2017). 


\section{Results and discussion}

\subsection{Categorization of the territory of the Czech Republic accord- ing to risk of occurrence of agricultural drought for winter wheat}

The aim of the analysis and mapping of the outcomes was to define areas with increased risk of agricultural drought occurrence during the critical growth and development phase of winter wheat vegetation (flowering) in the territory of the Czech Republic based on a sophisticated synthesis of a) long-term time series of agrometeorological data, b) long-term phenological time series of winter wheat, and c) soil conditions data (available water capacity of Czech soils) for the arable land category (Fig. 1). The risk of occurrence of agricultural drought for winter wheat according to drought indicator $\mathrm{aE} / \mathrm{pE}$ on the territory of the Czech Republic was categorized to six the same range intervals. Since in this case we deal with a relative risk

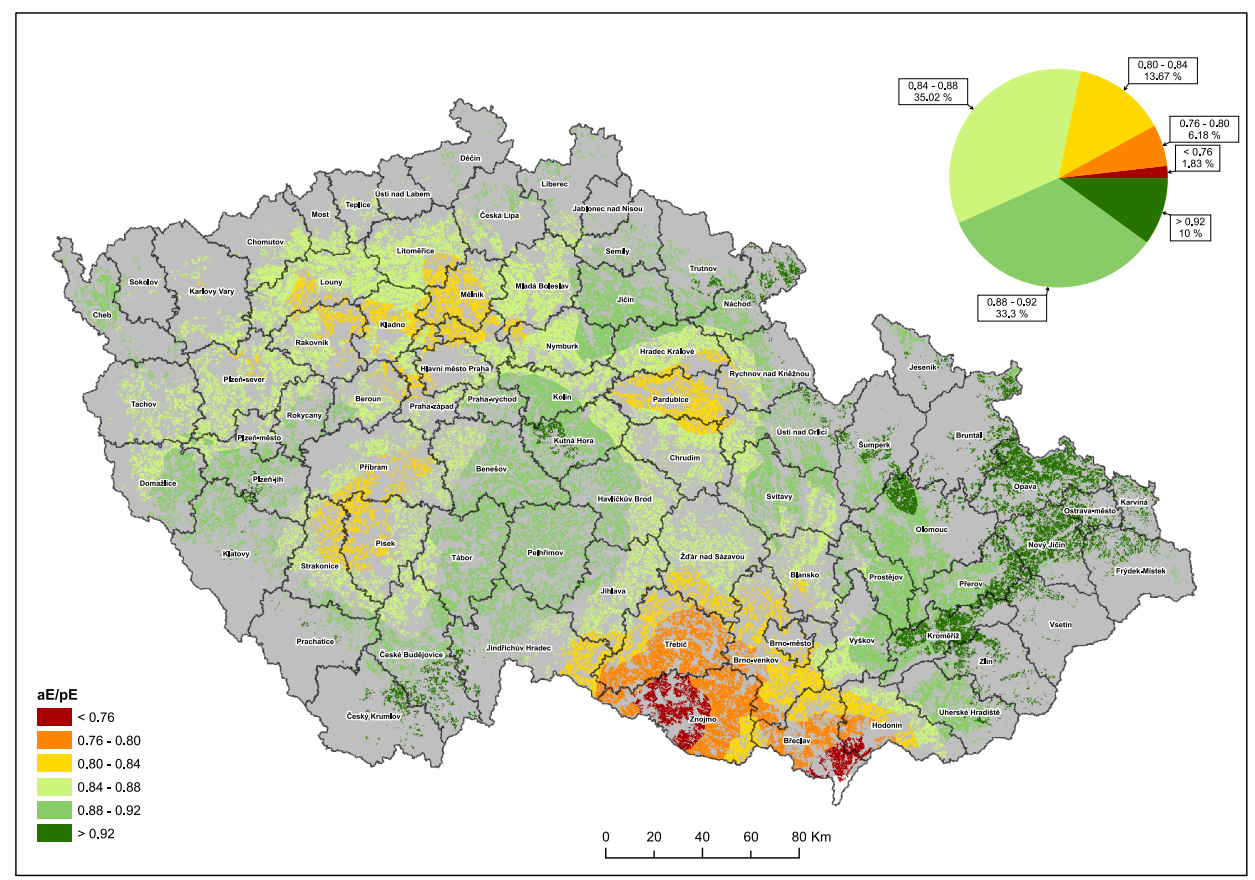

Fig. 1. Categorization of the territory of the Czech Republic using aE/pE according to the risk of occurrence of agricultural drought for winter wheat (1961-2010). 
quantification, these categories do not correspond to climatological or hydrologic drought categories.

In accordance with the research priorities of the Ministry of Agriculture for the period 2017-2025, the map provides partial information for optimization of crop representation in each locality, organization and optimization of farming techniques, use of minimization and soil conservation technologies for better soil retention, utilization of varieties tolerant to drought, and the potential for using an effective irrigation system at the time when plants most need water.

It should be possible to refine the application of countermeasures leading to soil protection, especially against wind erosion and nutrient loss, thus ensuring all of their functions and sustainable arable farming. The developed method (map) will, among other uses, be applicable to legislative and non-legislative documents of the Ministry of Agriculture intending to mitigate the impacts of agricultural activities on natural resources, including land. The documents are useful for the verification of previous outputs with possible application in the Ministry of Agriculture.

\subsection{Potential water balance in the growing season}

Rožnovský et al. (2015) used for the calculated long-term values of water balance from grassland $(\mathrm{mm})$ during vegetation period eight categories (less than $-150 \mathrm{~mm}$ to more than $150 \mathrm{~mm}$ ), out of which six were given by intervals of $50 \mathrm{~mm}$ and two tail (no danger risk of drought - exceptional risk of drought). Nevertheless, for our evaluation mere eight categories are insufficient, because water balance lower than $-150 \mathrm{~mm}$ fits for significant part of the Czech Republic. Verbal categorization of those categories has not been set yet.

Figs. 2 and 3 show the values of potential water balance for the periods of 1961-2010 and 2071-2100, respectively. For the period of 1961-2010, the most significant interval of water balance is the interval of 0 to $-50 \mathrm{~mm}$ (Table 1). This interval is represented broadly on $21.73 \%$ of the territory of the Czech Republic. Negative values of water balance show areas where potential evapotranspiration prevails over rainfall. A total of $71.55 \%$ of the Czech Republic is within the range of potential evapotranspiration from 0 to less than $-250 \mathrm{~mm}$. Water balance values in the growing season lower 


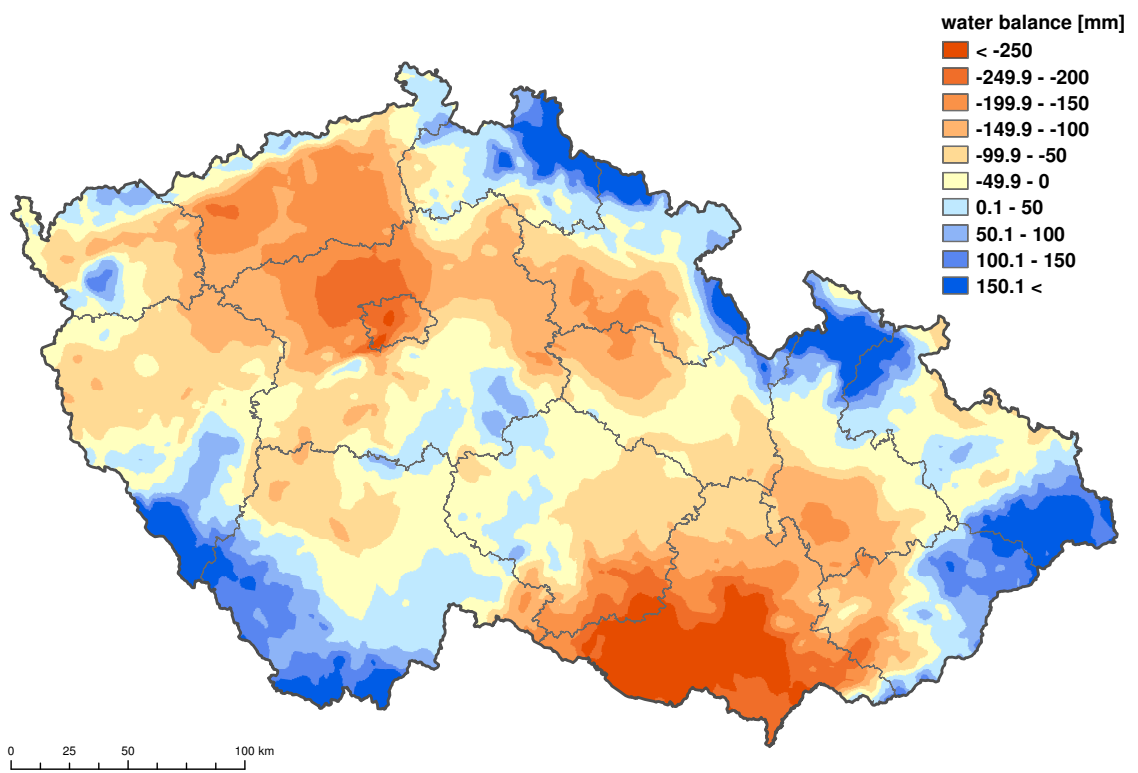

Fig. 2. Water balance in the growing season for the period of 1961-2010.

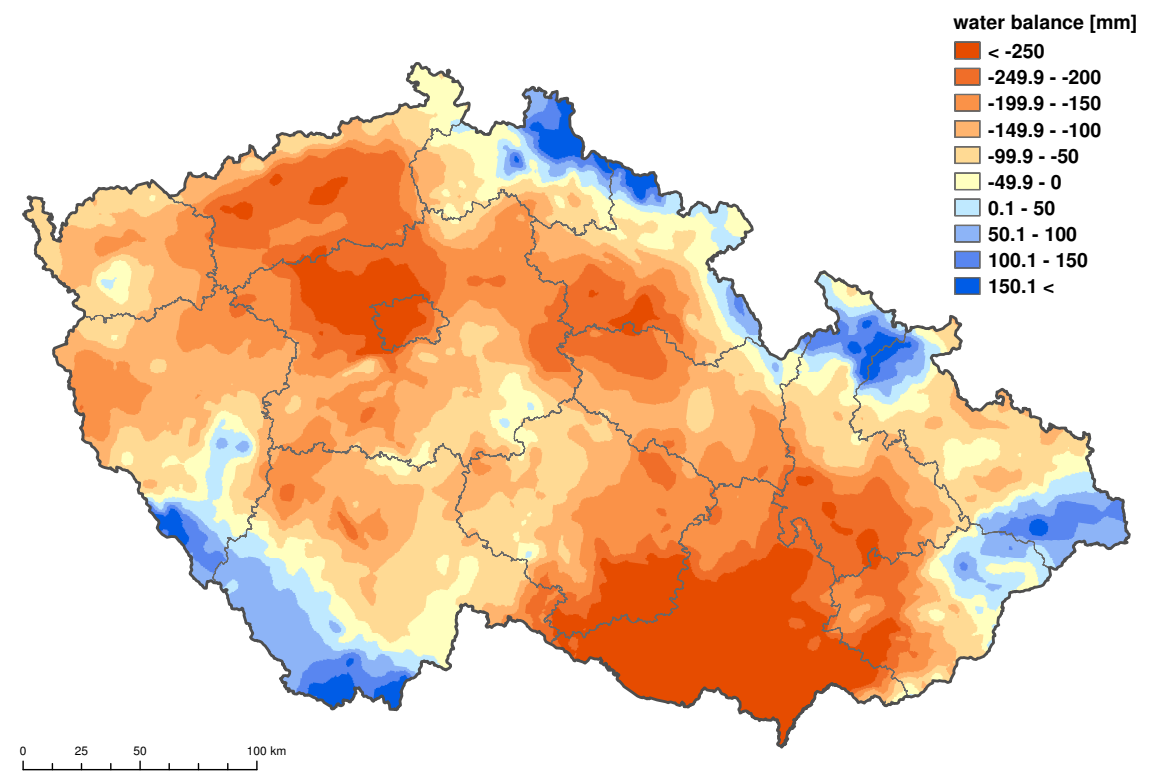

Fig. 3. Water balance in the growing season for the period of 2071-2100. 
than $-250 \mathrm{~mm}$ are typical for the most fertile parts of the Czech Republic (southern Moravia, Polabí), where the land is used mainly for agricultural purposes. Greater predominance of potential evapotranspiration over rainfall could pose a major problem in the future, especially in the context of drought threat. Additionally, in $28.43 \%$ of the territory of the Czech Republic, precipitation totals in the growing season are greater than potential evapotranspiration. These regions are mainly mountain and foothill areas. These findings should also be perceived in the context of officially set farm land prices, where the highest prices and, in theory, the most productive land correspond to sites where drought is already being monitored and is predicted to increase in the future. In the soils traditionally considered as the most fertile, water is gradually becoming a limiting factor.

Table 1. Area of individual categories of potential water balance in the growing season for 1961-2010 and 2071-2100.

\begin{tabular}{|c|c|c|c|}
\hline \multicolumn{2}{|c|}{$\mathbf{1 9 6 1 - 2 0 1 0}$} & \multicolumn{2}{|c|}{$\mathbf{2 0 7 1 - 2 1 0 0}$} \\
\hline $\mathbf{m m}$ & \% of the territory & $\mathbf{m m}$ & \% of the territory \\
\hline$<-250$ & 3.66 & $<-250$ & 10.99 \\
\hline$-250--200$ & 3.68 & $-250--200$ & 12.37 \\
\hline$-200--150$ & 8.59 & $-200--150$ & 17.34 \\
\hline$-150--100$ & 14.15 & $-150--100$ & 19.41 \\
\hline$-100--50$ & 19.74 & $-100--50$ & 18.60 \\
\hline$-50-\quad 0$ & 21.73 & $-50-0$ & 8.50 \\
\hline $0-50$ & 13.29 & $0-50$ & 4.59 \\
\hline $50-100$ & 5.69 & $50-100$ & 4.39 \\
\hline $100-150$ & 4.25 & $100-150$ & 2.33 \\
\hline $150<$ & 5.20 & $150<$ & 1.48 \\
\hline
\end{tabular}

A map layer of water balance during the growing season of 2071-2100 was created on the basis of emission scenario A1B (Intergovernmental Panel on Climate Change [IPCC]). Based on the analysis, in the future, potential evapotranspiration will prevail over precipitation in most of the territory of the Czech Republic, specifically $87.21 \%$ of the territory. According to estimates, this means a $15.66 \%$ increase compared to the period of $1961-$ 2010. In the period of 2071-2100, the largest part of the Czech Republic $(18.60 \%)$ will fall within the water balance range -100 to $-50 \mathrm{~mm}$. Consequently, a significant extension of sites with potential evapotranspiration predominant over precipitation is expected. In the future, a predominance 
of precipitation over potential evapotranspiration during the growing season is expected only in mountainous areas. Between 2071 and 2100, there will be a pronounced decline in water balance values at all altitudes compared to the reference period of 1961-2000. More frequent occurrence and higher intensity of drought can therefore be expected.

\section{Summary}

The innovative aspect of the method of categorization of the territory of the Czech Republic according to the risk of occurrence of agricultural drought for winter wheat is considering drought occurrence from the aspect of the plant, i.e., evaluation based on the actual need of water by the vegetation.

The resulting maps also define areas as at risk that appear to be less risky on standard maps; however, depending on actual precipitation, these areas correspond to areas of wheat agriculture affected by drought in recent years. The map therefore forms a basis for wheat cultivation targeted for relevant features and for regionalization of varieties.

The comparison of the water balance in the growing season for the periods of 1961-2010 and 1971-2100 predicts a significant deterioration of agricultural drought in the region.

Acknowledgements. This research was supported financially by the National Agency of Agricultural Research Ministry of Agriculture (project Nos. QJ1510098 and QK1720285).

\section{References}

Allen R. G., Pereira L. S., Raes D., Smith M., 1998: Crop evapotranspiration. Guidelines for computing crop water requirements. FAO Irrigation and Drainage Paper No. 56, FAO, Roma, 301 p.

Blum A., 2005: Drought resistance, water-use efficiency, and yield potential - are they compatible, dissonant, or mutually exclusive? Australian Journal of Agricultural Research, 56, 1159-1168, doi : 10.1071/AR05069.

Boyer J. S., 1982: Plant productivity and environment. Science, 218, 4571, 443-448, doi: $10.1126 /$ science.218.4571.443. 
Chuchma F., Středová H., Středa T., Rožnovský J., Svejkovská A., 2017: Climatic regionalization update in terms of estimated pedologic-ecological system (Aktualizace klimatických regionů v rámci systému bonitovaných půdně ekologických jednotek). Brno: Mendelova univerzita v Brně, 96 p. (in Czech).

Du S., Wang Y. L., Kume T., Zhang J. G., Otsuki K., Yamanaka N., Liu G. B., 2011: Sapflow characteristics and climatic responses in three forest species in the semiarid Loess Plateau region of China. Agricultural and Forest Meteorology, 151, 1-10, doi : 10.1016/j.agrformet.2010.08.011.

Hough M., Palmer S., Weir A., Lee M., Barrie I., 1997: The Meteorological Office Rainfall and Evaporation Calculation System: MORECS version 2.0. Meteorological Office, Bracknell, $82 \mathrm{p}$.

Jones H. G., 2007: Monitoring plant and soil water status: established and novel methods revisited and their relevance to studies of drought tolerance. Journal of Experimental Botany, 58, 2, 119-130, doi: 10.1093/jxb/erl118.

Kalvová J., Kašpárek L., Janouš D., Žalud Z., Kazmarová H., 2002: Specification of the climate change impact scenarios for the territory of the Czech Republic and estimation of this impact on hydrological regime, agricultural sector, forest management and human health in CR (Zpřesnění scénářů projekce klimatické změny na území České republiky a odhadi̊ projekce klimatické změny na hydrologický režim, sektor zemědělství, sektor lesního hospodářství a na lidské zdraví v ČR). NKP: Praha, 151 p. (in Czech).

Klimešová J., Procházková P., Středa T., 2017: Significant decreasing trend of moisture conditions during the growing season in the Central Europe. Proceedings of $24^{\text {th }}$ international PhD students conference (MENDELNET 2017). Mendel University in Brno, Brno, 76-80.

Kohut M., 2007: Water balance of agricultural landscape. Doctoral Dissertation, Mendel University in Brno, Brno, 128 p. (in Czech).

Kohut M., Rožnovský J., Chuchma F., 2009: The long-term soil moisture reserve variability in the Czech Republic based on the AVISO model. In: Sustainable Development and Bioclimate, Stará Lesná, Slovakia. Slovak Academy of Sciences: Bratislava, $160-161$.

Lawlor D. W., Day W., Johnston A. E., Legg B. J., Parkinson K. J., 1981: Growth of spring barley under drought: crop development, photosynthesis, dry-matter accumulation and nutrient content. The Journal of Agricultural Science, 96, 1, 167-186, doi: $10.1017 / \mathrm{S} 002185960003197 \mathrm{X}$.

Lipiec J., Doussan S., Nosalewicz A., Kondracka K., 2013: Effect of drought and heat stresses on plant growth and yield: a review. International Agrophysics, 27, 4, 463-477, doi : 10.2478/intag-2013-0017.

Matejka F., Hurtalová T., Rožnovský J., Chalupníková B., 2005: Effect of soil moisture on evapotranspiration of a maize stand during one growing season. Contributions to Geophysics and Geodesy, 35, 3, 219-228.

Naithani K. J., Ewers B. E., Pendall E., 2012: Sap flux-scaled transpiration and stomatal conductance response to soil and atmospheric drought in a semi-arid sagebrush 
ecosystem. Journal of Hydrology, 464-465, 176-185, doi: 10.1016/j.jhydrol.20 12.07 .008 .

Nikolova N., Nejedlík P., Lapin M., 2016: Temporal variability and spatial distribution of drought events in the lowlands of Slovakia. Geofizika, 33, 2, 119-135, doi: 10.15233/gfz.2016.33.10.

Penman H. L., 1948: Natural evaporation from open water, bare soil and grass. Proceedings of the Royal Society of London, Series A, 193, 1032, 120-145, doi : 10.1098/ rspa.1948.0037.

Procházková P., Chuchma F., Středa T., 2016: Drought severity in intensive agricultural areas by means of the EDI index. Contributions to Geophysics and Geodesy, 46, 4, 289-305, doi: 10.1515/congeo-2016-0017.

Rožnovský J., Kohut M., Chuchma F., 2015: Agricultural drought during vegetation period in the Czech Republic. Towards to Climatic Services, Nitra, Slovakia, 1-5.

She D., Xia Y., Shao M., Peng S., Yu S., 2012: Transpiration and canopy conductance of Caragana korshinskii trees in response to soil moisture in sand land of China. Agroforestry Systems, 87, 3, 1-10, doi : 10.1007/s10457-012-9587-4.

Skalák P., Štěpánek P., Farda A., 2008: Validation of ALADIN-Climate/CZ for present climate (1961-1990) over the Czech Republic. Időjárás, 112, 191-201.

Škvarenina J., Tomlain J., Hrvol J., Škvareninová J., Nejedlík P., 2009: Progress in dryness and wetness parameters in altitudinal vegetation stages of West Carpathians: Time-series analysis 1951-2007. Időjárás, 113, 47-54.

Středa T., Dostál V., Horáková V., Chloupek O., 2012: Effective use of water by wheat varieties with different root system sizes in rain-fed experiments in Central Europe. Agricultural Water Management, 104, 2, 203-209.

Středová H., Chuchma F., Středa T., 2011: Climatic factors of soil estimated system. Bioclimate: Source and limit of social development. Topolčianky, Slovakia, Nitra: SPU in Nitra, 137-138.

Středová H., Středa T., 2015: Agroclimatic conditions of the Czech Republic - development and influence on agricultural production. Seed and seedlings. Praha: Czech University of Life Sciences Prague, 22-27.

Thompson N., Barrie I. A., Ayles M., 1981: The Meteorological Office Rainfall and Evaporation Calculation System: MORECS. Meteorological Office, Bracknell, 45, 71 p.

Zeppel M. J. B., Macinnis-Ng C., Yunusa I. A. M., Whitley R. J., Eamus D., 2008: Long term trends of stand transpiration in a remnant forest during wet and dry years. Journal of Hydrology, 349, 1-2, 200-213, doi : 10.1016/j.jhydrol.2007.11.001. 